Uşak Üniversitesi Sosyal Bilimler Dergisi

$2016,9 / 1$

\title{
Okul Tutum Değerlendirme Ölçeğinin Psikometrik Özellikleri: Güvenirlik ve Geçerlik Çalışması
}

Murat BALKIS*

Gökmen ARSLAN**

Öz

$\mathrm{Bu}$ çalışmanın amacı Okul Tutum Değerlendirme Ölçeği'nin (OTDÖ) psikometrik özelliklerini araştırmaktır. Çalışmaya Isparta ìl Merkezinde lisede öğrenim gören toplam 751 (417 k1z, 334 erkek) öğrenci katılmıştır. Öğrencilerin yaşları 14 ile 19 arasında değişmektedir. Açımlayıcı ve doğrulayıcı faktör analizi sonuçları ölçeğin beş faktörlü yapısını desteklemektedir. Analiz sonuçlarına göre beş faktör öğrencilerin akademik başarıları ile beklenen yönde korelâsyonlar vermektedir. OTDÖ'nin iç tutarlılık güvenirliği .75 ile 91 arasında bulunmuştur. Bu sonuçlar OTDÖ'nin ülkemizdeki lise öğrencileri için geçerli ve güvenilir sonuçlar verdiğini göstermektedir.

Anahtar Kelimeler: Okul Tutum, Geçerlik, Güvenirlik.

\section{Psychometrics Properties of School Attitude Assessment Survey: A Study of Reliability and Validity}

\section{Abstract}

The study aimed to examine the psychometric properties of the School Attitudes Assessment Survey-Revised (SAAS-R) for Turkish high school sample. A total of 751 high school students (417 female, 334 male) participated in this study. The ages of the students ranged from 14 to 19 . Result of Exploratory and Confirmatory factor analyses verified a five factor structure, with a high inter-factor correlation. The results of criterion related validity also showed that the SAAS-R had criterion related validity. In addition, the results confirmed that the SAAS-R has high internal reliability. The findings of this study indicate that the SAAS-R is a valid and reliability results for high school students in Turkey.

Keywords: School Attitude, Validity, Reliability.

* Pamukkale Üniversitesi, Eğitim Fakültesi, Rehberlik ve Psikolojik Danışmanlık A.B.D., mbalkis@pau.edu.tr

** Süleyman Demirel Üniversitesi, Eğitim Fakültesi, Rehberlik ve Psikolojik Danışmanlık A.B.D., gokmenarslan@sdu.edu.tr 


\section{Giriş}

Birey çocukluk ve gençlik döneminin büyük bir kısmını eğitimöğretim süreci içerisinde geçirir. Çocukluk döneminden itibaren, gelecekteki yaşam koşulları okul ortamında şekillenir. Özellikle ergenlik döneminde eğitimsel açıdan kazanılan başarılar, yetişkinlik dönemindeki yaşam koşullarını belirlemede önemli bir faktördür (Suldo, Shaffer ve Shaunessy, 2008). Bu nedenle öğretmen, öğrenci, okul yöneticileri ve aileler, okulun öğrencilerin öğrenimlerini en üst düzeyde geçekleştirebilecekleri, kendilerini mutlu ve güvende hissedebilecekleri, öğretmenlerinden ve öğrenmekten hoşnut ve tatmin olabilecekleri bir yer olması gerektiği konusunda hem fikirdirler (Marks, 1998). Bu süreçte bazı öğrenciler kendilerinden beklenenin aksine, ödevlerini yapmama, sınavlara hazırlanmama, herhangi bir hazırlık yapmadan derse gelme gibi bir takım davranışlar sergilerler. Bu davranışları sergileyen öğrenciler genellikle başarısız öğrenciler olarak tanımlanır (McCoach ve Siegle, 2001).

Başarısızlık genellikle öğrencinin potansiyeli ile performansı arasındaki tutarsızlık olarak ele alınmaktadır (Reis ve McCoach, 2000). Okulun bireyin gelişim ve sosyalleşme sürecindeki aracı rolü düşünüldüğünde, öğrenci başarısızlığının beraberinde madde kullanımı, anti-sosyal davranışlar, okulu bırakma gibi birçok istenmeyen veya olumsuz sonuçlar doğurabileceği söylenebilir (Cheng ve Chan, 2014). Öğrenci başarısızlığı ile ilişkili ailesel, kişisel ve okula ilişkin birçok faktör bulunmaktadır. Yapılan çalışmalarda, akademik başarısı düşük olan öğrencilerin başarısı yüksek olanlara göre, akademik benlik algısı, motivasyon/öz düzenleme, amaca yönelik davranışlarının nispeten daha düşük, okula ve öğretmenlere yönelik tutumlarının ise daha olumsuz olduğu belirtilmektedir (McCoach ve Siegle, 2001; Reis ve McCoach, 2000).

Öğrenci başarısını etkileyen faktörlerden biri, öğrencinin okula ve öğretmenlerine yönelik tutumudur. Olumlu bir okul ortamı öğrencinin akademik başarısı üzerinde kolaylaştırıcı, diğer bir değişle olumlu etkiler bırakacaktır (Alıc1, 2013; Marks, 1998). Okula ilişkin olumsuz duygulara sahip olan ve okulda kaçma davranışı sergileyen bir öğrencinin başarısı ile okula karşı olumlu tutuma sahip, okulda bulunmaktan hoşlanan ve okulun önemine inanan bir öğrencinin okul içindeki performansı ve başarısı birbirinden elbette ki farklı olacaktır (Alıcl, 2013). Bu nedenle öğrencilerin okul ve öğretmenlerine ilişkin tutumlarının, başarıları ve okula ilişkin diğer yaşantıları üzerinde etkili bir faktör olduğu söylenebilir. Adıgüzel ve Karadaş (2013) okula ilişkin olumsuz tutuma sahip olan öğrencilerin okul devamsızlıklarının daha fazla olduğunu rapor etmektedir. Ayrıca Pişkin 
(2005) ve Bölükbaşı (2005) yaptıkları çalışmada akademik başarı ile okula ilişkin tutum arasında anlamlı bir ilişki bulmuşlardır.

Başarıyı etkileyen diğer önemli bir faktör olan motivasyon, sadece öğrencilerin akademik başarılarıyla değil, aynı zamanda öğrencilerin ne kadar öğrenecekleriyle de yakından ilişkilidir (Slavin, 2013). Bu nedenle başarısızlık yaşayan öğrencilerin diğerlerine oranla daha düşük motivasyona/öz düzenlemeye (Başlantı ve McCoach, 2006) sahip oldukları görülmektedir. Örneğin; McCoach ve Siegle (2001) öğrencinin bir amacının olması ve motivasyon/öz düzenlemenin başarının önemli yodayıcıları olduğunu bulmuşlardır. Bununla birlikte diğer bir çalışmada Peterson (2000) başarılı öğrencilerin başarısız öğrencilere göre daha amaca yönelik davranışlar sergilediklerini rapor etmiştir. Delisle ve Berger (1990) kendini başarısız olarak algılayan öğrencilerin başarıya ulaşma noktasında kendilerini sınırladıklarını belirtmiştir. Bu nedenle başarılı öğrenci ile başarısız öğrenci ayırımında kendilik algısı önemli bir rol üstelenmektedir (Ford, 1992). Bu bağlamda başarısızlık yaşayan öğrencilerin, başarıya ulaşma noktasında kendilerine olan inançlarının daha zayıf olduğu söylenebilir. Başlantı ve McCoach (2006) tarafından yapılan çalışmada, akademik başarısızlık yaşayan öğrencilerin diğer gruba göre daha düşük akademik benlik algısına, öğretmene ve okula yönelik daha olumsuz tutuma, daha düşük motivasyon/öz düzenlemeye, düşük düzeyde amaçsal yönelimlere sahip oldukları bulgularına ulaşılmıştır.

Alan yazın incelendiğinde, öğrencilerin başarısında önemli rol oynayan bu faktörlerin tek tek ele alındığı görülmektedir. $\mathrm{Bu}$ da bu faktörlerin öğrencilerin başarısındaki rolüne ilişkin daha bütüncül bir resmin görünmesini engelleyebilmektedir. Dolayısıyla, bireyin akademik başarısında rol oynayan faktörlerin bir bütün olarak incelenmesi bu faktörlerin rolüne ilişkin bütüncül bir resim sunabilir. Alan yazın incelendiğinde, McCoach(2002), McCoach ve Siegle (2003) tarafından geliştirilen Okul Tutum Değerlendirme Ölçeği' nin bu amaca hizmet edebileceği görülmüştür. Ayrıca belirtilen husus dışında iki önemli nedenden dolayı ölçeğin Türkçe'ye uyarlanma gereksinimi duyulmuştur. Bu nedenlerden ilki, Okul Tutum Değerlendirme Ölçeği beş farklı boyuta sahip olması nedeniyle, öğrencilerin akademik başarısında rol oynayan faktörlerin farklı boyutlarının anlaşılmasında bir avantaj sağlayacaktır. İkinci önemli neden ise, ölçekte madde sayısının çok fazla olmaması, katılımcıların zamanının sınırlı olduğu, birden fazla ölçme aracının kullanıldığı araştırmalarda rahatlıkla kullanılabilir olmasıdır. 


\section{Okul Tutum Değerlendirme Ölçeği (OTDÖYV) Yeni Versiyonunun Psikometrik Özellikleri}

McCoah(2002) tarafından Amerika Birleşik Devletleri'ndeki Ortaokul ve Lise öğrencilerinin okula yönelik tutumlarını saptamak için geliştirilen “Okul Tutum Değerlendirme Ölçeği"(School Attitudes Assessment Survey) nin ilk versiyonu 20 maddelik 7'li likert türü bir ölçektir. Ölçeğin ilk versiyonu, akademik benlik algısı, okula yönelik tutum, akran tutumları ve motivasyon/öz düzenleme olmak üzere dört faktörden oluşmaktadır. Daha sonra McCoah ve Siegle (2003) ölçeği yeniden düzenlemişlerdir. Yapılan düzenleme çalışması sonucunda ölçekteki madde sayısı 35'e yükseltilmiş ve böylelikle ölçeğin yeni versiyonu 35 maddelik 7'li likert türü bir ölçeğe dönüştürülmüştür. Bireylerden kendilerini her madde için 1(hiç katılmıyorum) ile 7(tamamen katılıyorum) puan aralığında derecelendirmeleri istenmektedir. Ölçeğin yeni versiyonu; akademik benlik alg1sı, okula yönelik tutum, öğretmenlere yönelik tutum, motivasyon/öz düzenleme ve amaç varlığı olmak üzere beş faktörden oluşmaktadır. Ölçeğin alt boyutlarına ait iç tutarlılık kat sayıları akademik benlik algısı için $\alpha=.86$, öğretmenlere yönelik tutum için $\alpha=.89$, okula yönelik tutum için $\alpha=$ .87 , amaçlar için $\alpha=.89$ ve motivasyon/öz düzenleme için $\alpha=.91$ olarak rapor edilmiştir (McCoah ve Siegle, 2003).

Okul Tutum Değerlendirme Ölçeğinin yeni versiyonu farklı ülke ve kültürlerde, farklı eğitim kademelerinde öğrenim gören öğrencilerin okula yönelik tutumlarını saptamak için kullanılmıştır. Taheri (2011) ölçeğin Farsça 'ya uyarlama çalışmasını yapmıştır. Yapılan analizler sonucunda ölçeğin, 35 madde ve beş alt boyuttan oluştuğunu rapor etmiştir. Başlantı ve McCoah(2006) tarafından ölçme aracının Türkiye' deki üniversite öğrencilerine yönelik uyarlama çalışması yapılmıştır. Uyarlama çalışması kapsamında dil eşdeğerlilik ve iç tutarlılık çalışması yapılmıştır. Yapılan analizler sonucunda ölçeğin alt ölçeklerine ait iç tutarlılık katsayılarının .81 ile .95 arasında değiştiği rapor edilmiştir. Ayrıca orijinal dil ile Türkçe versiyonu arasında yüksek düzeyde $(r=.907)$ ilişki bulunmuştur.

\section{Araştırmanın Amacı}

Bu çalışmada, alan yazınında önemli bir boşluğun doldurulmasına hizmet edeceği düşünülen Okul Tutum Değerlendirme Ölçeği' nin geçerlik, güvenirlik ve faktör yapısının, bir diğer ifadeyle psikometrik özelliklerinin lise öğrencileri üzerinde incelenmesi amaçlanmıştır. 


\section{Yöntem}

\section{Çalışma Grubu}

Araştırmanın çalışma grubunu, 2013-2014 öğretim yılının I. ve II. yarıyılında Isparta il merkezinde yer alan ortaöğretim kurumlarında öğrenim gören 9, 10, 11 ve 12. sınıfa devam eden, yaşları 14 ile 19 arasında değişen 751 (417 kız, 334 erkek) öğrenci oluşturmaktadır. Öğrencilerin yaş ortalaması 16,20 ve standart sapması 1.086 dir.

\section{Veri Toplama Araçları}

Araştırmada veri toplamak amacıyla Okul Tutum Değerlendirme Ölçeği Yeni Versiyonu ve kişisel bilgi formu kullanılmıştır.

Kişisel Bilgi Formu: Öğrencilere ait demografik bilgiler ve akademik başarı kişisel bilgi formu ile toplanmıştır.

\section{Verilerin Analizi Süreci}

Otuz beş maddeden oluşan ölçeğin İngilizce formu, ölçeği geliştiren araştırmacıdan izin alınarak, önce araştırmacılar tarafından Türkçe'ye çevrilmiş, daha sonra Eğitim Bilimleri alanından iki uzman tarafından Türkçe'den İngilizce'ye tekrar çevrilmiş, her iki dili etkili bir şekilde kullanabilen alandan üçüncü bir öğretim üyesi tarafından çeviriler karşılaştırılarak ölçeğe son şekli verilmiştir. Ölçeğin açımlayıcı ve doğrulayıcı faktör analizi için ayrı ayrı çalışma grupları kullanılmıştır. Faktör analizi yapılmadan önce maddeler arasında kısmi korelasyonların ve korelasyon matrisinin faktör analizi için uygun olup olmadığ $\breve{1}_{1}$ incelenmiştir. Önce açımlayıcı faktör analizi ( $\mathrm{N}=328)$, daha sonra bulunan yapının test edilmesi için doğrulayıcı faktör analizi $(\mathrm{N}=423)$ yapılmıştır. Daha sonra iç güvenirlik için veriler ayrıca analiz edilmiştir.

Verilerin analizinde SPSS 15 ve AMOS 7.0 (Arbucke, 2006) programı kullanılmıştır. Türkçeye uyarlanan ölçeğin yapı geçerliğini test etmek için açımlayıcı ve doğrulayıcı faktör analizinden yararlanılmıştır. Ölçeğin ölçüte dayalı geçerliğini incelemek için Mann-Whitney $U$ testi analizlerinden ve Pearson Momentler Çarpımı Korelasyon Katsayısından yararlanılmıştır. Türkçeye uyarlanan ölçeğin güvenirlik çalışması kapsamında ölçek maddelerinin birbirleriyle tutarlılığını incelemek için Cronbach'ın $\alpha$ katsayısı hesaplanmıştır. 


\section{Bulgular}

\section{Geçerlik Çalışmaları}

Modelin Uygunluğu: McCoah ve Siegle (2003) tarafından önerilen 35 madde ve beş faktörlü yapının Türkçe formunun uygunluğunu test etmek için öncelikle doğrulayıcı faktör analizi yapılmıştır. Doğrulayıcı faktör analizi(DFA) için 328 kişilik veri kullanılmıştır. Doğrulayıcı Faktör Analizinde, modelin geçerliğini test etmek için çok sayıda uyum indeksi kullanılmaktadır. Bu çalışmada Ki-kare uyum testi (Chi-Square Goodness), İyilik Uyum İndeksi (GFI), Karşılaştırmalı Uyum İndeksi (CFI), Normlaştırılmış Uyum İndeksi (NFI), Göreli Uyum İndeksi (RFI), Fazlalık Uyum İndeksi (IFI), ve Yaklaşık Hataların Ortalama Karekökü (RMSEA) uyum indeksleri incelenmiştir. Bu uyum indekslerinde genelde olduğu gibi GFI, CFI, NFI, RFI ve IFI >.90, ve RMSEA < .08 ölçüt olarak alınmıştır (Browne \& Cudeck, 1993; Hu \& Bentler, 1999; Kline, 2005).

DFA'da elde edilen modelin uyum indeksleri incelendiğinde Minimum Ki-kare değerinin $(\chi 2=1356.793, \mathrm{df}=550, \mathrm{p}<.001, \mathrm{~N}=328)$ ve $(X$ $2 / \mathrm{df}=2.467)$ anlamlı olduğu görülmüştür. Uyum indeksi değerleri ise $\mathrm{RMSEA}=.067(.062,071) \mathrm{CFI}=.87, \mathrm{TLI}=.86, \mathrm{IFI}=.87, \mathrm{GFI}=.81$, ve SRMR $=$ .068 olarak bulunmuştur. Doğrulayıcı faktör analizi sonucu 35 maddelik modelin kabul edilebilir düzeyde iyi uyum göstermediği görülmüştür. 35 maddelik modelin uygunluğunu test etmek için önce açımlayıcı ve daha sonra tekrar doğrulayıcı faktör analizi yapılmıştır.

Açımlayıcı Faktör Analizi: Faktör analizi yapılmadan önce maddeler arasında kısmi korelasyonların ve korelasyon matrisinin faktör analizi için uygun olup olmadığı Kaiser-Meyer- Olkin (KMO) katsayısı ve Barlett testi ile incelenmiştir (Fayers ve Machin, 1998). Yapılan analizlerde, Okul Tutum Değerlendirme ölçeğinin bütünü için (35 madde) Kaiser Meyer Olkin değerinin .93 olduğu görülmüş, Barlett testi sonucu, $\left[x^{2}=6562,127\right.$, $\mathrm{df}=595, \mathrm{p}$ <.000)] anlamlı bulunmuştur. Ölçeğin yapı geçerliğini ve faktör yapısını incelemek amacıyla açımlayıcı faktör analizi, faktörleştirme tekniği olarak da temel bileşenler analizi seçilmiştir. Ölçeğin yap1 geçerliğini belirlemek için, Kaiser normalleştirmesine göre özdeğeri (eigenvalue) 1.00'in üzerinde olan faktörler ölçüt alınmıştır.

Açımlayıcı faktör analizi bulguları incelendiğinde özdeğeri 1 den büyük olan toplam varyansın \% 62'092'sini açıklayan 6 faktör görülmüştür (Şekil 1). Analiz sonucunda herhangi bir faktöre yüklenmeyen ve kendi faktörü dışındaki faktörlere yüklenen 1, 10, 17, 21, 28, 32 ve 34. maddeler analizden çıkarılıp kalan 28 madde üzerinden yeniden faktör analizi yapılmıştır. Yapılan analizlerde, Okul Tutum Değerlendirme ölçeğinin 
bütünü için (28 madde) Kaiser Meyer Olkin değerinin. 93 olduğu görülmüş, Barlett testi sonucu, $\left[\mathrm{x}^{2}=5330,048, \mathrm{df}=378, \mathrm{p}<.000\right.$ )] anlamlı bulunmuştur.

Analizler toplam varyansın \% 37.374'ünü oluşturan 10.465 özdeğerli temel faktör olarak varsayılan birinci faktör (Motivasyon/Öz düzenleme) ile yine toplam varyansın \% 10, 671'ini oluşturan 2.988 özdeğerli ikinci bir faktör (Okula yönelik tutum), toplam varyansın \% 6.613'ünü oluşturan 1.852 özdeğerli üçüncü bir faktör (Amaç varlığı), toplam varyansın \% 5.150' sini oluşturan 1.442 özdeğerli dördüncü faktör (Öğretmenlere yönelik tutum) ve toplam varyansın \% 4.644' ünü oluşturan 1.300 özdeğerli beşinci faktör (Akademik benlik algisı) bulunmuştur. Beş faktörün toplam varyansın \% 64.452'sini açıkladığı görülmüştür. Ölçekte kalan tüm maddelerin faktör yüklerinin .44 ile .83 arasında olması, ölçekteki maddelerin, ölçekteki temsil edilebilirlik gücünün yüksekliğini göstermesi bakımından önemli görülmektedir (Tablo1).

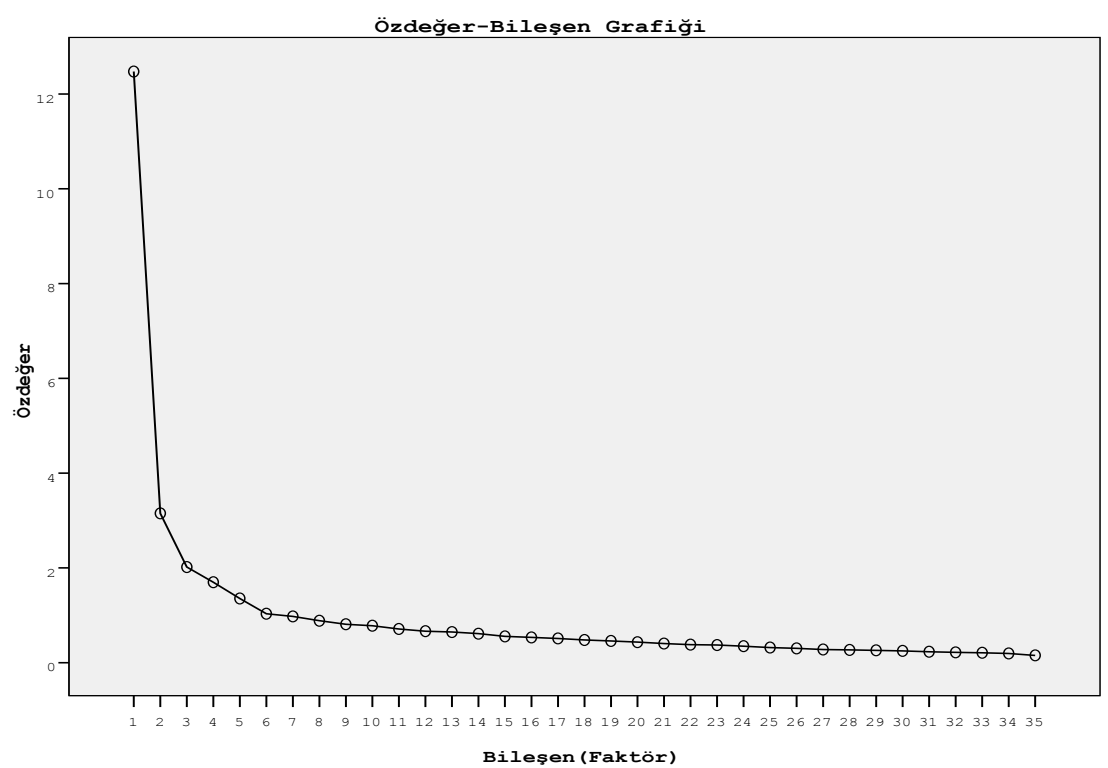

Şekil 1. Özdeğer-Bileşen Grafiği 
Tablo 1. Okul Tutum Değerlendirme Ölçeği'nin Madde Toplam Korelasyonları ve Faktör Yükleri

\begin{tabular}{|c|c|c|c|c|c|c|}
\hline & $\mathrm{r}$ & 1.Faktör & 2.Faktör & 3.Faktör & 4.Faktör & 5.Faktör \\
\hline M20 & .718 & .823 & & & & \\
\hline M17 & .742 & .770 & & & & \\
\hline M23 & .728 & .767 & & & & \\
\hline M27 & .756 & .750 & & & & \\
\hline M15 & .765 & .750 & & & & \\
\hline M7 & .689 & .673 & & & & \\
\hline M22 & .689 & .631 & & & & \\
\hline M5 & .587 & .631 & & & & \\
\hline M8 & .758 & & .832 & & & \\
\hline M3 & .796 & & .827 & & & \\
\hline M13 & .808 & & .813 & & & \\
\hline M4 & .767 & & .797 & & & \\
\hline M28 & .707 & & .739 & & & \\
\hline M16 & .693 & & & .761 & & \\
\hline M26 & .626 & & & .695 & & \\
\hline M19 & .754 & & & .681 & & \\
\hline M12 & .628 & & & .669 & & \\
\hline M18 & .679 & & & .580 & & \\
\hline M9 & .721 & & & & .793 & \\
\hline M11 & .714 & & & & .758 & \\
\hline M10 & .549 & & & & .658 & \\
\hline M21 & .606 & & & & .584 & \\
\hline M6 & .513 & & & & .518 & \\
\hline M1 & .387 & & & & & .761 \\
\hline M2 & .563 & & & & & .719 \\
\hline M25 & .558 & & & & & .600 \\
\hline M14 & .535 & & & & & .570 \\
\hline M27 & .546 & & & & & .443 \\
\hline
\end{tabular}

Not: $N=328, r=$ Madde-toplam korelasyon değerleri

Doğrulayıcı Faktör Analizi (DFA): Doğrulayıcı faktör analizini yapmak için Okul Tutum Değerlendirme ölçeği 423 lise öğrencisine uygulanmıştır. 28 madde üzerinden yapılan DFA'da elde edilen modelin uyum indeksleri incelendiğinde Minimum Ki-kare değerinin $(\chi 2=1037.489$, $\mathrm{df}=340, \mathrm{p}<.001, \mathrm{~N}=423)$ ve $\left(X^{2} / \mathrm{df}=3.051\right)$ anlamlı olduğu görülmüştür. Uyum indeksi değerleri ise RMSEA $=.070(.065,075) \mathrm{CFI}=.92$, TLI $=.91$, IFI= .92 , GFI $=.83$, ve SRMR $=.064$ olarak bulunmuştur. Doğrulayıcı faktör analizi 
sonucu 28 maddelik modelin kabul edilebilir düzeyde uyum gösterdiği ortaya çıkmıştır (Şekil 2). Alt ölçekler arasındaki korelasyon kat sayılarının ise ( $r=.41$ ile. 62) arasında değiştiği görülmüştür (Tablo2).

Tablo 2. Okul Tutum Değerlendirme Ölçeğinin Alt Boyutları ve Akademik Başarı Arasındaki Korelasyon Katsayıları ( $\mathrm{N}=373$ )

\begin{tabular}{lcccccc}
\hline & $\mathbf{1}$ & $\mathbf{2}$ & $\mathbf{3}$ & $\mathbf{4}$ & $\mathbf{5}$ & $\mathbf{6}$ \\
\hline 1-Akademik Başarı & - & $.332^{* *}$ & $.194^{* *}$ & $.400^{* *}$ & $.244^{* *}$ & $.302^{* *}$ \\
2-Akademik Benlik & & - & $547^{* *}$ & $.411^{* *}$ & $.416^{* *}$ & $.574^{* *}$ \\
Alg1s1 & & & & & & \\
3-Ögrretmene Yönelik & & & - & $.558^{* *}$ & $.540^{* *}$ & $.616^{* *}$ \\
Tutum & & & & & & \\
4- Okula Yönelik & & & & - & $.490^{* *}$ & $.455^{* *}$ \\
Tutum & & & & & & \\
5-Motivasyon/Öz & & & & & - & $.539^{* *}$ \\
düzenleme & & & & & & \\
6-Amaç Varlığ1 & & & & & & - \\
Aritmetik Ortalama & 83.30 & 25.36 & 23.08 & 23.01 & 34.38 & 28.14 \\
Standart Sapma & 14.12 & 6.20 & 6.80 & 8.90 & 11.88 & 7.68 \\
\hline
\end{tabular}

Not: $N=373,{ }^{* *} p<.01$

Ölçüte Dayalı Geçerlik Çalışması: Okul Tutum Değerlendirme Ölçeği'nin ölçüte dayalı geçerliğini test etmek için iki yol izlenmiştir. İlk olarak Okul Tutum Değerlendirme ölçeğinin alt boyutlarına ait puanların, öğrencilerin akademik başarıları arasındaki ilişkiye bakılmış. Yapılan analizler akademik başarı ile okul tutum değerlendirme ölçeğinin bütün boyutları arasında $(\mathrm{p}<.01)$ düzeyinde pozitif bir ilişki olduğu görülmüştür (Tablo2). İkinci olarak ölçeğin ölçüte dayalı geçerliğini test etmek için öğrenciler akademik başarıları açısından (alt ve üst grup) gruplandırılarak, ölçeğin alt boyutlarındaki puan farklılıkları test edilmiştir. Öğrencilerin akademik başarıları açısından gruplamak için, öncelikle dağılımın normal olup olmadığını test etmek için Shapiro-Wilk testi uygulanmış ve gözlem değerlerinin normal dağılım göstermediği anlaşılmıştır $\left(\mathrm{D}_{(373)}=.879, \mathrm{p}<.001\right)$. Dağılımın normal olmamasından dolayı, ortanca (medyan) kat sayısından yararlanılarak öğrenciler başarıları açısından alt ve üst grup şekilde gruplandırılmıştır. Ölçeğin alt boyutlardaki puan ortalamalarının gruplar açısından farklılaşıp farklılaşmadığını test etmek için Mann-Whitney U testi analizleri yapılmış. Okul Tutum Değerlendirme ölçeğinin beş alt boyutuna ait puan ortalamalarının alt ve üst gruplara farklılaştığı ve bu farklılığında ( $p<.001)$ düzeyinde anlamlı olduğu görülmüştür (Tablo3). 
Tablo 3. Okul Değerlendirme Ölçeğinin Alt boyutlarının Üst ve Alt başarı Gruplarına Göre Mann-Whitney U Testi Analiz Sonuçları

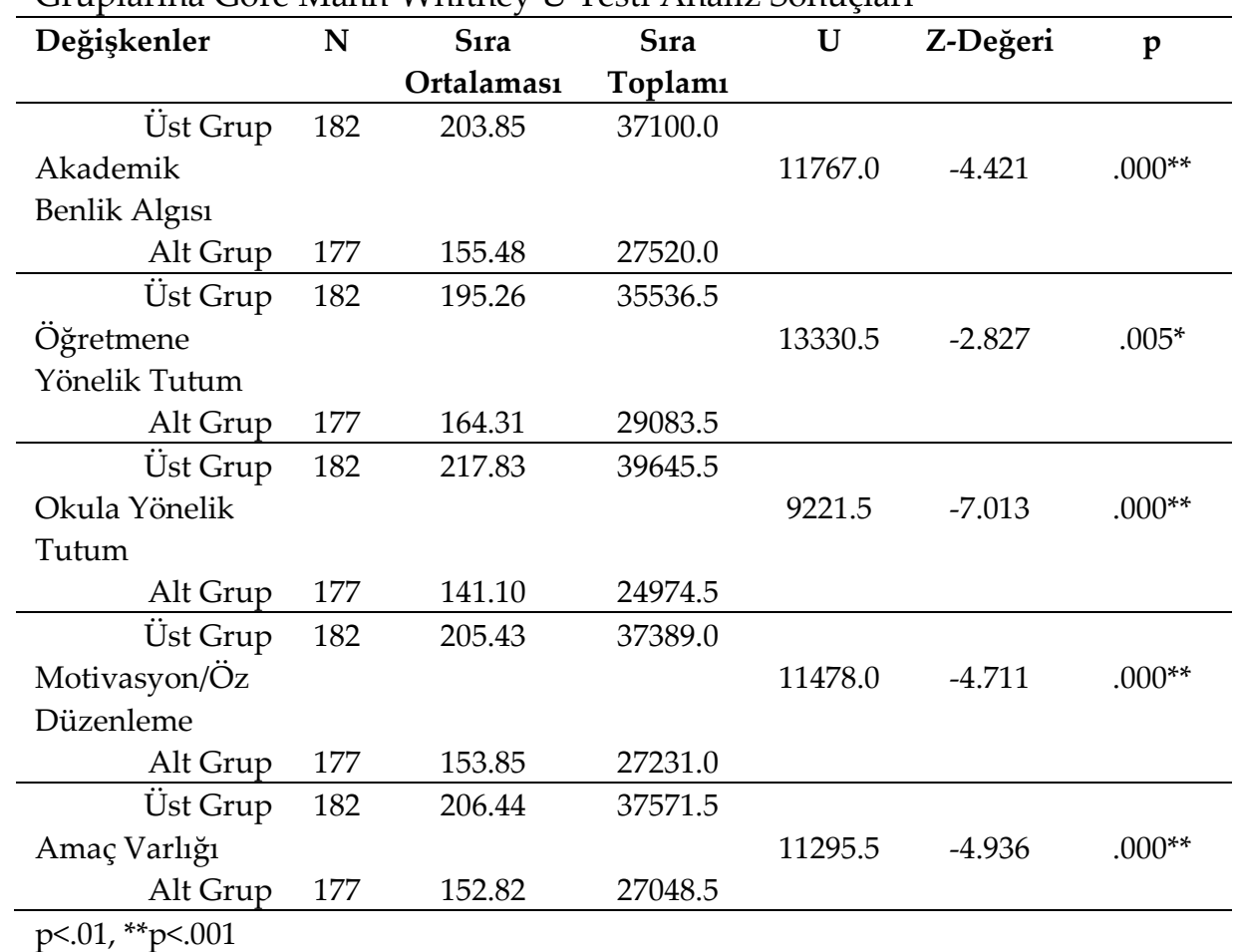

Tablo 3 incelediğinde, akademik başarısı yüksek olan öğrencilerin, Okul Tutum Değerlendirme Ölçeğinin tüm boyutlarındaki puan ortalamalarının akademik başarısı düşük olan öğrencilerin puan ortalamalarından daha yüksek olduğu sahip olduğu ve bu farklılığında istatistiksel olarak anlamlı olduğu görülmektedir. Diğer bir ifadeyle, olumlu benlik algısına, öğretmene ve okula yönelik tutumu olumlu olan, motivasyon/öz düzenleme düzeyi yüksek ve amaçları olan öğrencilerin akademik başarılarının daha yüksek olduğu söylenilebilir. 


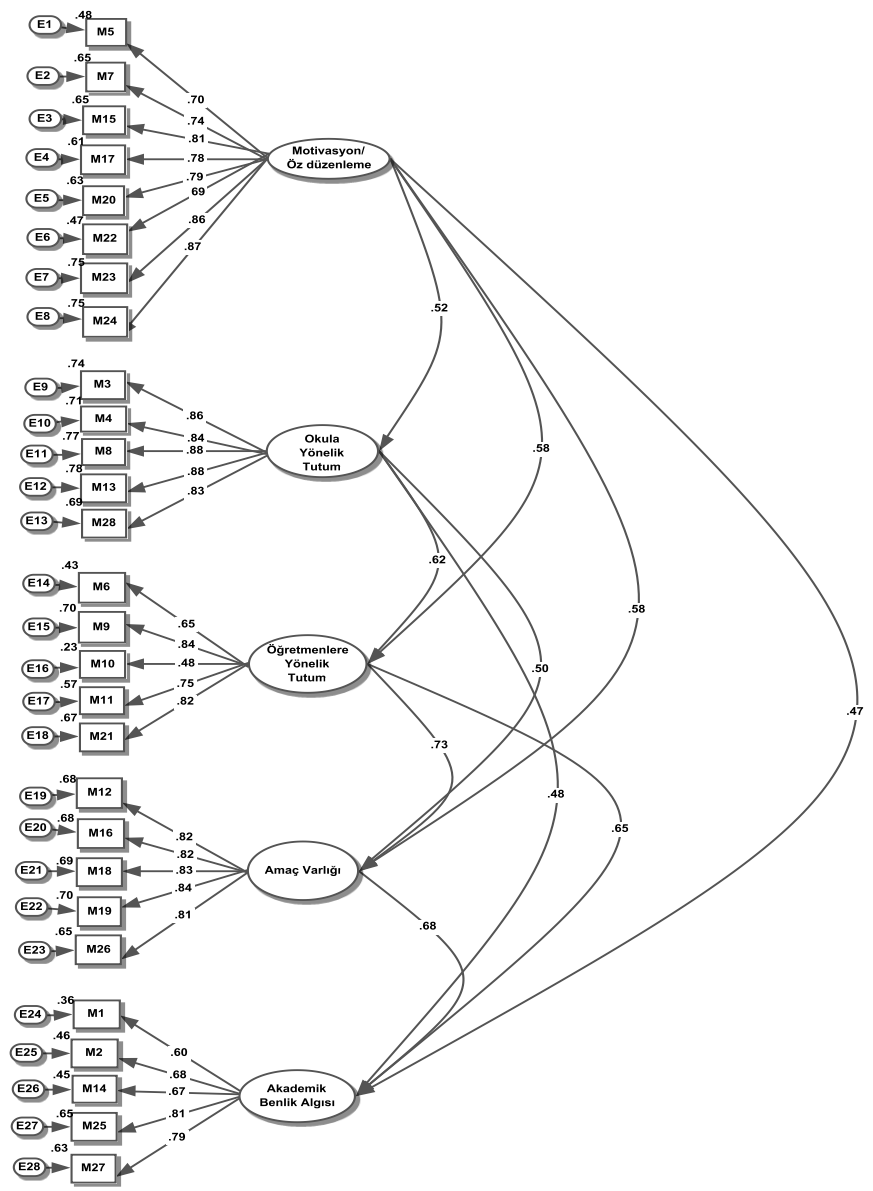

Şekil 2. Doğrulayıcı faktör analizi sonuçları (N=423)

\section{Güvenirlik Çalışmaları}

Okul Tutum Değerlendirme ölçeğinin güvenirliği için ölçeğin iç tutarlık katsayılarına (Cronbach alfa) bakılmıştır. Veriler $(\mathrm{N}=328)$ üzerinde yapılan analizlerde, tüm ölçeğin iç tutarlılık güvenirliği. 94 olarak bulunmuştur. Bu sonuç, ölçek maddelerinin benzeşikliğinin ve maddelere verilen yanıtların tutarlılığının yüksek olduğunu göstermektedir. Ölçeğin alt ölçeklerinin iç güvenirlik katsayıları, Motivasyon/Öz düzenleme boyutu için $\alpha=.91$, Okula yönelik tutum boyutu için $\alpha=.91$ Amaç varlığ boyutu için $\alpha=$ .86, Öğretmenlere yönelik tutum boyutu için $\alpha=.83$ ve Akademik benlik 
alg1sı boyutu için $\alpha=.75$ olarak bulunmuştur. Madde toplam korelasyonlarının ise .39 ile .81 arasında değiştiği görülmektedir (Tablo 1).

\section{Sonuçlar ve Tartışma}

Bu çalışmanın temel amacı, Okul Tutumu Değerlendirme Ölçeği'nin psikometrik özelliklerini lise öğrencileri üzerinde test etmektir. Ölçeğin faktör yapısına ilişkin analizler, ölçeğin orijinal çalışmasına paralel olarak, ölçeğin ülkemizde de kullanılabileceğini göstermiştir. Analiz sonuçları ayrıca, ölçeğin yüksek iç tutarlılık güvenirliğine sahip olduğunu göstermektedir.

Ölçeğin faktör yapısını test etmek için yapılan açımlayıcı faktör analizleri ölçeğin, Motivasyon/Öz düzenleme, Okula yönelik tutum, Öğretmenlere yönelik tutum, Amaç mevcudiyeti ve Akademik benlik algıSı olmak üzere birbirleriyle pozitif yönde ilişkili beş alt boyuttan oluştuğunu göstermektedir. Bu korelasyon katsayıları ölçeğin orijinal çalışmasında da elde edilen değerlerle ( $\mathrm{r}=.41$ ile .62 arasında değişen) benzerlik göstermektedir. Analiz sonucunda elde edilen özdeğeri 10.465 olan birinci faktör "Motivasyon/Öz düzenleme" olarak, özdeğeri 2.988 olan ikinci bir faktör "Okula yönelik tutum" olarak, özdeğeri 1.852 olan üçüncü faktör "Amaç varlığı" olarak, özdeğeri 1.442 olan dördüncü faktör "Öğretmenlere yönelik tutum" ve özdeğeri 1.300 olan beşinci faktör "Akademik benlik algısı" olarak isimlendirilmiştir. Beş faktör birlikte okul tutum değerlendirme varyansın \% 64'452'sini açıklayabilmektedir. Açımlayıcı faktör analizi sonucunda ölçekte kendi faktörleri dişındaki faktörlere yüklenen 7 madde ölçekten çıkarılmış ve ölçekteki madde sayısı 28 olmuştur. Ölçekte kalan tüm maddelerin faktör yüklerinin 44 ile .83 arasında değiştiği görülmüştür. 28 maddelik ölçeğin faktör yapısını doğrulamak amacıyla farklı bir örneklem üzerinde yapılan doğrulayıcı faktör analizi sonuçları da 28 maddelik ölçeğin beş boyutlu yapısını desteklemiştir. Doğrulayıcı faktör analizinde elde edilen uyum indeksleri ile ölçeğin orijinal çalışmasında elde edilen uyum indeksleri benzerlik göstermektedir (McCoach ve Siegel, 2003).

Ölçeğin ölçüte dayalı geçerlik çalışması için öğrencilerin akademik başarıları kullanılmıştır. İlk olarak, Okul Tutum Değerlendirme ölçeğinin alt boyutları ile akademik başarı arasındaki korelasyonlara bakılmıştır. Korelasyon analizleri öğrencilerin akademik başarılarının ölçeğin bütün alt boyutlarıla olumlu yönde ilişkili olduğunu göstermiştir. İkinci olarak, ölçeğin ölçüte dayalı geçerliğini test etmek için öğrenciler akademik başarıları açısından alt ve üst gruplara ayrılmıştır. Okul Tutum Değerlendirme Ölçeğinin alt boyutlarının gruplara göre farklılaşıp 
farklılaşmadığına bakılmıştır. Yapılan Mann Whitney-U testi analizleri ölçeğin bütün boyutlarından alınan puan ortalamalarının gruplara göre farklılık gösterdiği görülmüştür. Akademik başarı açısından üst grupta yer alan öğrencilerin ölçeğin bütün boyutlarındaki puan ortalamalarının daha yüksek olduğu görülmüştür. Bu bulgular McCoach (2002), McCoach ve Siegel (2003), Suldo ve ark. (2007)'nın bulgularıyla tutarlılık göstermektedir. Özetle, geçerlik çalışması kapsamında yapılan bütün analizler Okul Tutum Değerlendirme ölçeğinin Türkiye'deki lise öğrencileri için geçerli bir araç olarak kullanılabileceğini göstermektedir.

Ölçeğin güvenirliği ile ilgili yapılan analizler, ölçeğin tüm alt boyutlarının iç tutarlılıklarının yüksek olduğunu göstermiştir. Ölçeğin alt boyutlarının iç tutarlılık kat sayılarının .75 ile .91 arasında değiştiği görülmüştür. Ölçek madde toplam korelasyonları açısından incelendiğinde korelasyon kat sayılarının .39 ile .81 arasında değiştiği görülmüştür. Bütün bu bulgular ölçeğin güvenilir bir ölçek olarak kullanılabileceğini göstermektedir.

Sonuç olarak, çalışma kapsamında elde edilen tüm bulgular Okul Tutum Değerlendirme Ölçeğinin Türkiye'deki lise öğrencileri için güvenilir ve geçerli sonuçlar verdiğini göstermektedir. Bu çalışma kapsamında psikometrik özellikleri test edilen ölçme aracının eğitim-öğretim süreci içerisinde akademik başarısızlık ve devamsızlık problemleri olan öğrencilere yönelik geliştirilecek önleyici ve müdahale edici çalışmalarda, okul psikolojik danışmanlarına büyük katkı sağlayacağı düşünülmektedir. Ayrıca öğretmenler ve psikolojik danışmanlar Okul Tutum Değerlendirme Ölçeğinden yararlanarak öğrencilerin devamsızlık ve akademik başarısızlık gibi önemli problemlerinin nedenlerini saptayabilirler.

Yukarıda verilen analiz sonuçları sınırlılıkları içinde değerlendirilmelidir. Ölçeğin farklı eğitim kademelerinde (Örneğin: ilkokul, ortaokul) öğrenim gören örneklemlerde de geçerlik ve güvenirlik çalışmalarının yapılmaması araştırmanın önemli bir sınırlılığı olarak değerlendirilebilir. Bu nedenle ölçeğin, ileride yapılacak çalışmalarda farklı eğitim kademelerinde de geçerlik ve güvenirliğinin test edilmesinin önemli olduğu düşünülmektedir.

\section{Kaynakça}

Adıgüzel, A., \& Karadaş, H. (2013). Ortaöğretim öğrencilerinin okula ilişkin tutumlarının devamsızlık ve okul başarıları arasındaki ilişki, YYÜ Eğitim Fakültesi Dergisi, 10 (1),49-66.

Alıcı, D. (2013). Okula yönelik tutum ölçeği'nin geliştirilmesi: Güvenirlik ve geçerlik çalışması. Eğitim ve Bilim, 38(168), 319-331. 
Başlantı, U., \& McCoach, D. B. (2006). Factors related to the underachievement of university students in Turkey. Roeper Review, 28(4), 210-215.

Bölükbaşı, B. (2005). The impact of family environment, self-concept, and school attitude on 9th grade students' academic achievement. Yayınlanmamış Yüksek Lisans Tezi. Boğaziçi Üniversitesi: İstanbul.

Browne, M. W., \& Cudeck, R. (1993). Alternative ways of assessing model fit. In K. A. Bollen \& J. S. Long (Eds.), Testing structural equation models (pp. 136-162). Newbury Park, CA: Sage.

Cheng, S. T., \& Chan, A. C. (2003). The development of a brief measure of school attitude. Educational and Psychological Measurement, 63(6), 1060-1070.

Delisle, J., \& Berger, S. L. (1990). Underachieving gifted students. ERIC Clearinghouse. Retrieved from http://www.kidsource.com/ kidsource/content/underachieving_gifted.html

Fayers, P.M., \& Machin, D. (1998). Quality of live assessment in clinical trials, methods and practice (Ed. Staquet, M, Hays, R. D. and Fayers, P.M.), New York, Oxford University Press.

Ford, D. Y. (1992). Determinants of underachievement as perceived by gifted, above average and average Black students. Roeper Review, 14, 130-136.

Hu, L., \& Bentler, P. M. (1999). Cutoff criteria for fit indexes in covariance structure analysis: conventional criteria versus new alternatives. Structural Equation Modeling, 6, 1-55.

Kline, R. B. (2005). Principles and practice of structural equation modeling (2nd ed.). New York: Guilford.

Marks, G. N. (1998). Attitudes to school life: their influences and their effects on achievement and leaving school" (1998). LSAY Research Reports. Longitudinal surveys of Australian youth research report; n.5.Retrieved from http://research.acer.edu.au/lsay_research/62

McCoach, D. B. \& Siegle, D. (2001-April). Why try? Factors that differentiate underachieving gifted students from high achieving gifted students. Paper presented at the Annual Meeting of the American Educational Research Association. Seattle, WA, USA.

McCoach, D. B. (2002). A validation study of the school attitude assessment survey. Measurement and Evaluation in Counseling and Development, 35(2), 66-77.

McCoach, D.B.,\& Siegel, D. (2003). The school attitude assessment surveyrevised: A new instrument to identify academically able students 
who underachieve. Educational and Psychological Measurement, 63(3), 414-429.

Peterson, J. S. (2000). A follow-up study of one group of achievers and underachievers four years after high school graduation. Roeper Review, 22, 217-224.

Pişkin, B. (2005). Öğrencilerin okula yönelik tutumlarını etkileyen etmenler, Yayınlanmamış Yüksek Lisans Tezi, Kocaeli Üniversitesi.

Reis, S. M. \& McCoach, D. B. (2000). The underachievement of gifted students: What do we know and where do we go? Gifted Child Quarterly, 44, 152-170.

Slavin, R. (2013). Eğitim Psikolojisi: Kuram ve Uygulama (Çev Ed.: Yüksel, G), Ankara: Nobel Akademi Yayıncilık.

Suldo, S. M., Shaffer, E. J., \& Shaunessy, E. (2008). An independent investigation of the validity of the school attitude assessment survey revised. Journal of Psychoeducational Assessment. 26(1), 69-82.

Taheri, Z. (2011). An investigation of effective factors on students' motivational beliefs: The case of Iranian students. Europe's Journal of Psychology, 7(1), 62-80. 
M. BALKIS, G. ARSLAN 16 